\title{
Kontribusi Konsep Diri Akademik dan Motivasi terhadap Prestasi Belajar Bahasa Inggris serta Implikasinya dalam Penyusunan Program Pelayanan Bimbingan dan Konseling di Bidang Belajar
}

Sesilianus Fau, Firman \& Mudjiran

Universitas Negeri Padang, Universitas Negeri Padang \& Universitas Negeri Padang

e-mail: Sesilianusfau@gmail.com

\begin{abstract}
The background of this research wasthe variation ofstudents achievement in learningEnglishatschool. Academic self-concept and motivation were assumed to have the most dominant effect on students' achievement in school. The purposes of this study were: (1) to describe the academic self-concept, (2) motivation, (3) the achievement of English learning, (4) to test the contribution of academic self-concept to English learning achievement, (5) to test contribution of motivation to English learning achievement, (6) to test the contribution of academic self-concept and motivation to English learning achievement, and (7) to describe the preparation of Guidance and Counseling program to improve academic self-concept, motivation, and students' achievement in the school. This research was done through quantitative approach with descriptive correlational method and qualitative approach. The population in this study was the students of XII IPA 1 to 4 of SMA 8 Padang. The sample was chosen by using simple random sampling. Meanwhile, informants in qualitative approach were the teachers of Guidance and Counseling. The Instrument used in the quantitative approach was questionnaire. On the other hand, the key instrument in the qualitative approach was the researcher. Quantitative data were analyzed by using descriptive statistics, simple linear regression and multiple regression. While, qualitative data were analyzed by using Miles and Huberman's model. The findings of this research showed that: (1) the average description of the academic self-concept of students was in medium category, (2) students' motivation to learn was at high category, (3) the students' English learning achievement was at goodcategory, (4) there is a contribution of academic self-concept to the students' English learning achievement amounted to $20.3 \%(R=0.451$, sig. 0.000), (5) there is a contribution of motivation to English learning achievement of students amounted to 32.9\% $(R=0.573$, sig. 0.000), (6) there are contributions of both academic self-concept and motivation to the students' English learning achievement amounted to $60.1 \%(R=0.775$, sig. 0.000), and (7) most of the Guidance and Counseling program for XII class of SMAN 8 Padang A.Y. 2015/2016 have been arranged well and the materials related to the improvement of academic self-concept, motivation, and students' achievement have been contained and written in the Guidance and Counseling program that has been arranged.
\end{abstract}

Keywords: Academic Self-concept, Motivation, Learning Achievement

Copyright (C2016 Universitas Negeri Padang All rights reserved

\section{PENDAHULUAN}

Keberhasilan belajar siswa yang ditunjukkan oleh nilai belajar yang tinggi serta diiringi sikap dan tingkah laku yang terpuji merupakan idaman atau harapan semua orangtua, guru, serta siapapun yang menaruh perhatian terhadap pendidikan. Akan tetapi, kenyataan menunjukkan bahwa tidak semua siswa di sekolah mampu mengikuti kegiatan belajar dengan baik dan memperoleh keberhasilan yang gemilang. Kondisi ini dimungkinkan karena siswa mengalami masalah dalam belajarnya, seperti malas belajar, kurang konsentrasi dalam mengikuti pelajaran, kurangnya niat dan usaha keras untuk meraih prestasi belajarnya, rasa mengantuk 
saat proses belajar berlangsung, mengabaikan guru dan/atau mata pelajaran yang tidak disenangi,sering bolos, kurang yakin dengan kemampuan yang dimiliki, kesulitan dalam pemahaman dan penggunaan bahasa asing dan/atau Bahasa Inggris, dan sebagainya.

Prayitno dkk.(2014:187); Tu'u (2004:76) menyatakan bahwa prestasi belajar merupakan buah dari kegiatan belajar dan bukti betapa kegiatan belajar itu dilaksanakan secara serius,berupa nilai atau angka yang dicapai siswa dalam proses pembelajaran di sekolah.

Keberhasilansiswa mencapai prestasi belajar yang baik dipengaruhi oleh berbagai macam faktor. Faktor itu meliputi faktor internal dan eksternal. Faktor internal meliputi faktor jasmaniah (kesehatan, cacat tubuh), faktor psikologis (inteligensi, perhatian, minat, bakat, motivasi, kematangan, dan kesiapan), faktor kelelahan, dan faktor cara belajar. Sedangkan, faktor eksternal meliputi faktor keluarga, sekolah, lingkungan belajar, fasilitas belajar, dan profesionalisme pendidik (Slameto,2010:54-72). Merson, U. S (dalam Tu'u, 2004:78) juga mengemukakan bahwa faktor penting yang mempengaruhi prestasi belajar adalah (1) kecerdasan, (2) bakat, (3) minat dan perhatian, (4) motivasi, (5) kesehatan, (6) cara belajar, (7) lingkungan keluarga, pergaulan, dan sekolah, dan (8) sarana pendukung belajar.

Berdasarkan data awal yang diperoleh di SMAN 8 Padang melalui hasil pengolahan AUM Umum dan PTSDL format SLTA menunjukkan rendahnya konsep diri akademik dan motivasi siswa untuk belajar, seperti: sering malas belajar, tidak mengulangi kembali materi yang diberikan oleh guru pada pelajaran sebelumnya sebagai persiapan untuk mengikuti pelajaran berikutnya, tidak mengejar ketinggalan materi apabila terpaksa tidak masuk sekolah, tidak berusaha membeli atau meminjam dari perpustakaan atau teman apabila tidak memiliki buku pelajaran tertentu yang dibutuhkan, kurang konsentrasi dalam mengikuti pelajaran, kesulitan dalam mengingat materi pelajaran, tugas-tugas pelajaran tidak selesai pada waktunya, tidak memperbaiki tugas yang dikembalikan guru sesuai dengan catatan dan komentar yang diberikan walaupun tidak akan dikumpulkan dan dinilai kembali, mengabaikan guru dan/atau mata pelajaran yang tidak disenangi, hasil belajar atau nilai-nilai kurang memuaskan, mengalami kesulitan dalam pemahaman dan penggunaan Bahasa Inggris atau bahasa asing lainnya, belum mengetahui bakat diri sendiri untuk jabatan/pekerjaan apa, dan belum mampu merencanakan masa depan.

Sehubungan dengan itu, hasil analisis data nilai hasil belajar UAS mata pelajaran Bahasa Inggris siswa kelas XIIIPA 1 s/d. 4 SMAN 8 Padang juga menunjukkan bervariasinya data prestasi belajar siswa di mata pelajaran tersebut. Dimana siswa yang nilainya di bawah KKM atau yang tidak lulus pada mata pelajaran tersebut sebanyak 91 orangdari 129 siswaatau sekitar 70,5\%. Sedangkan, siswa yang nilainya di atas KKM atau yang lulus pada mata pelajaran tersebut hanya 38 orang dari 129 siswa atau sekitar 29,5\%.Berdasarkan data tersebut terindikasi bahwa siswa memiliki prestasi belajar Bahasa Inggris yang rendah dan faktor yang paling dominan mempengaruhinya yaitu konsep diri akademik dan motivasi.

Marsh dan Rhonda (dalam Villegas dkk., 2013:117) mengemukakan bahwa konsep diri akademik merupakansalah satu variabelyang paling pentingdalam domainakademik, karenasecara langsungmempengaruhiproses belajar, prestasi belajar, dan ekspektasi (harapan) siswa, serta membantu siwa untukmenciptakan berbagaistrategipengaturan diri dan kognitif, yang mencerminkan pada kinerjaakademik. Bahkan,Liu (2009:414) menyatakan konsep diriakademik merupakan salah satu penentu utama prestasi belajar. Caraterbaik untuk meningkatkan prestasi belajar siswa adalah meningkatkan konsep diri akademik.

Bong dkk. (dalam Villegas dkk., 2013:119) mengemukakan bahwa siswa yang memiliki konsep diriakademik yang tinggi senang menerimatantangan, mengambil risiko, mencoba sesuatu yangbarudanjugamembuat beberapastrategikognitif, menyelesaikan tugas-tugas akademik yang sulit dan menetapkan tujuan akademik yang lebih tinggi, serta berkinerja tinggi secara akademik. Selanjutnya, Amezcua dkk. (dalam Villegas dkk., 2013:119); Combs dkk. (dalamBurns,1979:362)menjelaskan bahwa siswa yang memiliki konsep diri akademik rendah cenderung menghasilkan pencapaian prestasi yang rendah atau nilai yang rendah, kurang percaya diri pada bakat/kemampuan akademiknya, meremehkan atau menilai rendah bakatnya, menghindari situasi yang dapat menyebabkan kecemasan, kurang memiliki sumber daya kognitif, kurang memiliki motivasi yang positif, dan berkinerja rendah secara akademik.

Sehubungan dengan penjelasan di atas, Borislow (dalam Burns, 1979:360) mengemukakan bahwa selain faktor konsep diri akademik yang mempengaruhi prestasi belajar siswa, apakah setiap siswa memiliki 
kemauan keras untuk mera1h keberhasilan. Dalam artian, apakah setiap siswa memilik1 motıvası yang kuat atau yang tinggi untuk belajar demi mencapai prestasi belajarnya atau tidak. Hal ini sesuai dengan apa yang dikemukakan oleh Purwanto (2007:60) bahwa motivasi merupakan syarat mutlak dalam belajar agar siswa dapat terhindar dari perilaku-perilaku belajar yang tidak baik seperti malas belajar, membolos, dan sebagainya. Tanpa motivasi tidak akan timbul perbuatan seperti belajar. Sardiman (2014:84) juga menegaskan bahwa intensitas motivasi seorang siswa akan sangat menentukan tingkat pencapaian prestasi belajarnya. Tanpa motivasi, siswatidak akan mungkin melakukan aktivitas belajar.

Lebih lanjut, Dalyono (2010:235-236) mengemukakan bahwa motivasi menentukan baik tidaknya prestasi belajar siswa. Semakin besar motivasi siswa untuk belajar, semakin besar pula kesuksesan belajarnya. Oleh karena itu, siswa yang motivasinya tinggi atau kuat akan giat berusaha, tampak gigih tidak mau menyerah, giat membaca buku-buku untuk meningkatkan prestasinya. Sebaliknya, siswa yang memiliki motivasi rendah atau lemah, tampak acuh tak acuh, mudah putus asa, perhatiannya tidak tertuju pada pelajaran, suka mengganggu kelas, sering meninggalkan pelajaran akibatnya banyak mengalami kesulitan belajar.Sardiman (2014:75,85)juga menegaskan bahwa prestasi belajar atau hasil belajar akan optimal kalau ada motivasi yang tepat. Makin tepat motivasi yang diberikan, akan makin berhasil pula pelajaran itu. Bahkan, siswa yang memiliki inteligensi cukup tinggi sekalipun, boleh jadi gagal karena kekurangan motivasi.Hal ini dikarenakan motivasi berfungsi sebagai pendorong usaha dan pencapaian prestasi.

Berdasarkan uraian di atas, terlihat bahwa adanya hubungan konsep diri akademik dan motivasi terhadap prestasi belajar siswa. Namun, bagaimana besar kecilnya kontribusi antara faktor-faktor tersebut, maka perlu dilakukan penelitian. Untuk itu, tujuan penelitianini adalah sebagai berikut: (1) mendeskripsikan konsep diri akademik siswa, (2) mendeskripsikan motivasi siswa, (3) mendeskripsikan prestasi belajarBahasa Inggris siswa, (4) menguji kontribusi konsep diri akademik terhadap prestasi belajar Bahasa Inggris siswa, (5) menguji kontribusi motivasi terhadap prestasi belajarBahasa Inggris siswa, (6) menguji kontribusikonsep diri akademik dan motivasi secara bersama-sama terhadapprestasi Bahasa Inggris siswa, (7) mendeskripsikan penyusunan program BK dalam meningkatkan konsep diri akademik, motivasi, dan prestasi belajar siswa di sekolah.

\section{METODOLOGI}

Penelitian ini menggunakan pendekatan kuantitatif dengan metode deskriptif korelasional dan pendekatan kualitatif. Populasi dalam penelitian ini adalah siswakelas XII IPA 1 s/d. 4 SMA Negeri 8 Padang yang berjumlah 129 orang siswa. Sampel dalam penelitian ini sebanyak 97 orang siswa. Penarikan sampel menggunakan teknik simple random sampling. Sedangkan, informan dalam pendekatan kualitatif yaitu guru BK. Instrumen yang digunakan dalam pendekatan kuantitatif yaitu kuesioner. Sedangkan, instrumen dalam pendekatan kualitatif yaitu peneliti.Data penelitiankuantitatif dianalisis dengan statistik deskriptif, regresi linier sederhana, dan regresi ganda. Analisis data dibantu dengan menggunakan program SPSS versi 17.00. Sedangkan, data penelitian kualitatif dianalisis dengan model Miles dan Huberman.

\section{HASIL}

\section{Deskripsi Data}

Data dalam penelitian ini meliputi variabel konsep diri akademik $\left(\mathrm{X}_{1}\right)$, motivasi $\left(\mathrm{X}_{2}\right)$, dan prestasi belajar Bahasa Inggris (Y). Berikutini dikemukakan deskripsi data hasil penelitian.

\section{Konsep Diri Akademik $\left(\mathbf{X}_{1}\right)$}

Deskripsi data konsep diri akademik yang berjumlah97 responden dapat dilihat pada Tabel 1. 
Tabel 1. Distribusi Frekuensi dan PersentaseKonsep Diri Akademik

\begin{tabular}{llll}
\hline \multicolumn{1}{c}{ Interval Skor } & \multicolumn{1}{c}{ Kategori } & Frekuensi & \% \\
\hline $\mathbf{2 1 5 5}$ & Sangat Tinggi & 0 & 0 \\
$\mathbf{1 2 5 - 1 5 4}$ & Tinggi & 36 & 37.11 \\
$\mathbf{9 5 - 1 2 4}$ & Sedang & 61 & 62.89 \\
$\mathbf{6 5 - 9 4}$ & Rendah & 0 & 0 \\
$\mathbf{5 6 4}$ & Sangat Rendah & 0 & 0 \\
Total & & 97 & 100 \\
\hline
\end{tabular}

Berdasarkan Tabel 1 di atas terlihat bahwa sebagian besar siswa memiliki konsep diri akademik yang sedang yaitu sebesar $62.89 \%$, dan sebagian siswa berada pada kategori tinggi yaitu sebesar $37.11 \%$. Sedangkan, secara rata-rata tingkat capaian responden sebesar $66.3 \%$. Jadi, secara rata-ratakonsep diri akademik siswa berada pada kategori sedang.

\section{Motivasi $\left(\mathbf{X}_{2}\right)$}

Deskripsi data motivasi yang berjumlah 97 responden dapat dilihat pada Tabel 2.

\section{Tabel 2. Distribusi Frekuensi dan Persentasi Motivasi}

\begin{tabular}{llll}
\hline \multicolumn{1}{c}{ Interval Skor } & \multicolumn{1}{c}{ Kategori } & Frekuensi & \% \\
\hline $\mathbf{1 5 1}$ & Sangat Tinggi & 0 & 0 \\
$\mathbf{1 2 2 - 1 5 0}$ & Tinggi & 89 & 91.75 \\
$\mathbf{9 3 - 1 2 1}$ & Sedang & 8 & 8.25 \\
$\mathbf{6 4 - 9 2}$ & Rendah & 0 & 0 \\
$\mathbf{5 6 3}$ & Sangat Rendah & 0 & 0 \\
Total & & 97 & 100 \\
\hline
\end{tabular}

Berdasarkan Tabel 2di atas terlihat bahwa sebagian besar siswa memiliki motivasi yang tinggi yaitu sebesar $91.75 \%$, dan sebagian siswa berada pada kategori sedang yaitu sebesar $8.25 \%$. Sedangkan, secara rata-rata tingkat capaian responden sebesar $72.1 \%$. Jadi, secara rata-ratamotivasi siswa berada pada kategori tinggi.

\section{Prestasi Belajar Bahasa Inggris (Y)}

Deskripsi data prestasi belajar Bahasa Inggris yang berjumlah 97 responden dapat dilihat pada Tabel 3.

Tabel 3. Distribusi Frekuensi dan Persentase Prestasi Belajar Bahasa Inggris

\begin{tabular}{llll}
\hline \multicolumn{1}{c}{ Interval Skor } & \multicolumn{1}{c}{ Kategori } & Frekuensi & \% \\
\hline $\mathbf{9 9 5}$ & Istimewa & 1 & 1,03 \\
$\mathbf{8 0 - 9 4}$ & Amat Baik & 51 & 52.58 \\
$\mathbf{6 5}-\mathbf{7 9}$ & Baik & 45 & 46.39 \\
$\mathbf{5 5 - 6 4}$ & Cukup & 0 & 0 \\
$\mathbf{3 1 - 5 4}$ & Kurang & 0 & 0 \\
$\mathbf{3 3 0}$ & Amat Kurang & 0 & 0 \\
Total & & 97 & 100 \\
\hline
\end{tabular}

Berdasarkan Tabel 3di atas terlihat bahwa sebagian besar siswa memiliki prestasi belajar Bahasa Inggris yang amat baik yaitu sebesar $52.58 \%$, sebagian siswa berada pada kategori baik yaitu sebesar $46.39 \%$, kemudian pada kategori istimewa sebesar $1.03 \%$. Sedangkan, secara rata-rata tingkat capaian responden sebesar $79.3 \%$. Jadi, secara rata-rata prestasi belajar Bahasa Inggrissiswa berada pada kategori baik. 
(Kontribusi Konsep Diri Akademik dan Motivasi Terhadap Prestasi Beljar Bahasa Inggris Serta Implikasinya dalam Penyususnan Program Pelayanan Bimbingan dan Konseling di Bidang

Belajar)

\section{PengujianPersyaratanAnalisis Data}

Uji persyaratan analisis yang dilakukan pada data penelitian ini adalah uji normalitas, uji linieritas, dan uji multikolinieritas.

\section{UjiNormalitas}

Pengujian normalitas dilakukan dengan menggunakan metode Kolmogorov-Smirnov.Jika Asymp. Sig. atau $P$-value $>$ dari 0.05 (taraf signifikansi), maka data berasal dari populasi yang berdistribusi normal.

Berdasarkan hasil dari uji normalitas data, maka data nilai Asymp. Sig. konsep diri akademik sebesar 0.062, motivasi sebesar 0.118, dan prestasi belajar Bahasa Inggris sebesar 0.062lebih besar dari 0.05 ,sehingga ketiga variabel berdistribusi normal.

\section{Uji Linieritas}

Uji linieritas dalam penelitian ini memanfaatkan program SPSS 17.00. Jika nilai $F_{\text {hitung }} \geq F_{\text {tabel }}$, maka dinyatakan linier, dan jika nilai $\mathrm{F}_{\text {hitung }}<\mathrm{F}_{\text {tabel }}$, maka dinyatakan tidak linier (Yusuf, 2013:290).

Berdasarkanhasilujilinieritas, didapatkanhasilbahwa hubungan konsep diri akademik dengan prestasi belajar Bahasa Inggrisadalah linier denganF $F_{\text {hitung }}$ (23.868)> $F_{\text {tabel }}$ (3.94). Selanjutnya, data hubungan motivasi siswa dengan prestasi belajar Bahasa Inggrisjuga linier denganF $F_{\text {hitung }}(41.722)>F_{\text {tabel }}(3.94)$.

\section{Uji Multikolinieritas}

Berdasarkanujimultikolinieritasdiperoleh nilai VIFkonsep diri akademik sebesar 1.014 dan nilai VIFmotivasi sebesar 1.014< 10. Berdasarkan hasiltersebutdapatdisimpulkanbahwa tidak terjadi multikolinieritas antara variabel konsep diri akademik dengan variabel motivasi.

\section{Kontribusi Konsep DiriAkademik dan Motivasi terhadap Prestasi Belajar Bahasa Inggris}

\section{KontribusiKonsep DiriAkademik terhadap Prestasi Belajar Bahasa Inggris}

Hasilanalisis kontribusi konsep diri akademik terhadap prestasi belajar Bahasa Inggris dapat dilihat padaTabel 4.

\section{Tabel 4. Hasil Analisis Regresi Sederhana dan Uji Signifikansi $X_{1}$ terhadap $Y$}

\begin{tabular}{llllll}
\hline \multicolumn{1}{c}{ Model } & $\mathbf{R}$ & & $\mathbf{R}$ Square & Sig. \\
\hline $\mathbf{X}_{\mathbf{1}} \mathbf{- Y}$ & 0.451 & & 0.203 & & 0.000 \\
\hline
\end{tabular}

Pada Tabel 4 memperlihatkan bahwa nilai R sebesar 0.451, yang menunjukkan koefisien regresi antara konsep diri akademik terhadap prestasi belajar Bahasa Inggris, dengantarafsignifikan 0.000. Nilai $\mathrm{R}$ Square $\left(\mathrm{R}^{2}\right)$ sebesar 0.203 , ini berarti $20.3 \%$ variasi padaprestasi belajar Bahasa Inggris dapat dijelaskan oleh konsep diri akademik, sedangkan sisanya $79.7 \%$ dijelaskan oleh variabel lain.

\section{Kontribusi Motivasi terhadap Prestasi Belajar Bahasa Inggris}

Hasilanalisis kontribusi motivasi terhadap prestasi belajar Bahasa Inggris dapat dilihatpadaTabel 5.

Tabel 5. Hasil Analisis Regresi $\quad$ Sederhana dan UjiSignifikansi $X_{2}$ terhadap $Y$

\begin{tabular}{|c|c|c|c|}
\hline Model & $\mathbf{R}$ & R Square & Sig. \\
\hline $\mathbf{X}_{2}-\mathrm{Y}$ & 0.573 & 0.329 & 0.000 \\
\hline
\end{tabular}

Pada Tabel 5 memperlihatkan bahwa nilai R sebesar 0.573, yang menunjukkan koefisien regresi antara motivasi terhadap prestasi belajar Bahasa Inggris, dengantarafsignifikan 0.000 . Nilai $R$ Square $\left(\mathrm{R}^{2}\right)$ 
sebesar 0.329, ini berarti $32.9 \%$ variasi padaprestasi belajar Bahasa Inggris dapat dijelaskan oleh motivasi, sedangkan sisanya $67.1 \%$ dijelaskan oleh variabel lain.

\section{Kontribusi Konsep DiriAkademik dan Motivasi terhadap Prestasi Belajar Bahasa Inggris}

Hasilanalisis kontribusi konsep diri akademik dan motivasi terhadap prestasi belajar Bahasa Inggris dapat dilihat padaTabel 6 .

Tabel 6.Hasil Analisis Regresi Ganda danUjiSignifikansiX $X_{1}$ danX $X_{2}$ terhadap Y

\begin{tabular}{|c|c|c|c|}
\hline Model & $\mathbf{R}$ & R Square & Sig. \\
\hline$X_{1}, X_{2}-Y$ & 0.775 & 0.601 & 0.000 \\
\hline
\end{tabular}

Pada Tabel 6 memperlihatkan bahwa nilai R sebesar 0.775, yang menunjukkan koefisien regresi ganda antara konsep diri akademik dan motivasi terhadap prestasi belajar Bahasa Inggris, dengantarafsignifikan 0.000. Nilai R Square $\left(\mathrm{R}^{2}\right)$ sebesar 0.601 , ini berarti $60.1 \%$ konsep diri akademik dan motivasi berkontribusi secara bersama-samaterhadap prestasi belajar Bahasa Inggris, sedangkan sisanya $39.9 \%$ dijelaskan oleh variabel lain.

\section{PEMBAHASAN}

\section{Prestasi Belajar Bahasa Inggris}

Hasil analisis data penelitian menunjukkan bahwa secara rata-rata keseluruhan prestasi belajar Bahasa Inggris siswa kelas XII IPA SMAN 8 Padang siswa berada pada kategori baik. Menurut Prayitno dkk. (2014:187); Tu'u (2004:76) bahwa prestasi belajar merupakan buah dari kegiatan belajar dan bukti betapa kegiatan belajar itu dilaksanakan secara serius berupa nilai atau angka yang dicapai siswa dalam proses pembelajaran di sekolah. Sehingga, prestasi belajar menjadi salah satu indikator keberhasilan studi yang akan menjadi pertimbangan bagi penentuan nasib siswa berkaitan dengan studi yang dijalaninya.

Keberhasilan siswa mencapai prestasi belajar yang baik dipengaruhi oleh berbagai macam faktor, baik itu faktor kecerdasan, bakat, minat dan perhatian yang tinggi dalam pembelajaran, motivasi yang baik dalam belajar, cara belajar yang baik, dan strategi pembelajaran variatif yang dikembangkan oleh guru. Selain itu, lingkungan sekolah yang tertib, teratur, disiplin, yang kondusif bagi kegiatan kompetisi siswa dalam pembelajaran (Tu'u, 2004:81).Berbagai faktor yang mempengaruhi prestasi belajar tersebut di atas masing-masing memiliki kontribusi terhadap pencapaian prestasi belajar siswa dan dari berbagai faktor tersebut diantaranya adalah konsep diri akademik dan motivasi siswa untuk belajar. Oleh karena itu, faktor-faktor tersebut diduga memberikan kontribusi paling dominan pada prestasi belajar siswa di sekolah.

Berdasarkan uraian di atas diketahui bahwa secara rata-rata gambaran prestasi belajar Bahasa Inggris siswa berada pada kategori baik. Akan tetapi, apabila berdasarkan KKM, ada beberapa siswa yang tidak tuntas.

\section{Konsep Diri Akademik}

Hasil analisis data penelitian menunjukkan bahwa secara rata-rata keseluruhan konsep diri akademik siswa berada pada kategori sedang. Berdasarkan pencapaian masing-masing indikator yaitu perasaan siswa tentang kompetensi akademik, persepsi siswa tentang kompetensi akademik, dan keterlibatan siswa dalam kegiatan belajar secara rata-rata berada pada kategori sedang. Sedangkan, indikator komitmen siswa untuk belajar berada pada kategori tinggi.

Menurut Villegas dkk. (2013:117) konsep diri akademik merupakan persepsi dan penilaian siswa terhadap kemampuan akademiknya, yang berpengaruh pada studi dan fungsi kognitifnya.siswa yang memiliki konsep diriakademik yang tinggi senang menerimatantangan, mengambil risiko, mencoba sesuatu yangbarudanjugamembuat beberapastrategikognitif, menyelesaikan tugas-tugas akademik yang sulit dan menetapkan tujuan akademik yang lebih tinggi, serta berkinerja tinggi secara akademik. Sedangkan, siswa yang memiliki konsep diri akademik rendah cenderung menghasilkan pencapaian 
prestası yang rendah atau nilaı yang rendah, kurang percaya dirı pada bakat/kemampuan akademıknya, meremehkan atau menilai rendah bakatnya, menghindari situasi yang dapat menyebabkan kecemasan, kurang memiliki sumber daya kognitif, kurang memiliki motivasi yang positif, dan berkinerja rendah secara akademik.

Berdasarkan uraian di atas diketahui bahwa secara rata-rata gambaran konsep diri akademik siswa berada pada kategori sedang.

\section{Motivasi}

Hasil analisis data penelitian menunjukkan bahwa secara rata-rata keseluruhan motivasi siswa berada pada kategori tinggi. Berdasarkan pencapaian masing-masing indikator yaitu keingintahuan, pencapaian prestasi, kesenangan, dan keterpaksaan secara rata-rata berada pada kategori tinggi. Sedangkan, indikator imbalan dan ancaman akan hukuman berada pada kategori sedang.

Menurut Ormrod (2008:58); Purwanto (2007:73)motivasi adalah segala sesuatu yang menggerakkan, mengarahkan, dan mempertahankan perilaku seseorang untuk bertindak melakukan sesuatu hingga mencapai hasil atau tujuan tertentu. Jadi, apa saja yang diperbuat manusia, yang penting maupun yang kurang penting, yang berbahaya maupun yang tidak mengandung risiko, selalu ada motivasinya, termasuk motivasi dalam belajar.

Berdasarkan uraian di atas diketahui bahwa secara rata-rata gambaran motivasi siswa berada pada kategori tinggi.

\section{Kontribusi Konsep Diri Akademik terhadap Prestasi Belajar Bahasa Inggris}

Hasil penelitian menunjukkan bahwa konsep diri akademik berkontribusi secara signifikan terhadap prestasi belajar Bahasa Inggris. Temuan ini diperoleh berdasarkan analisis data yang menunjukkan bahwa kontribusi konsep diri akademik terhadap prestasi belajar Bahasa Inggris sebesar 20,3\%. Artinya, konsep diri akademik merupakan salah satu faktor yang berkontribusi atau menentukan prestasi belajar Bahasa Inggris siswa. Dalam artian, konsep diri akademik memiliki peran penting dalam mendukung dan meningkatkan prestasi belajar siswa. Hal ini sesuai dengan yang dikemukakan oleh Liu (2009:414) bahwa konsep diriakademik merupakan salah satu penentu utama prestasi belajar. Caraterbaik untuk meningkatkan prestasi belajar siswa adalah meningkatkan konsep diri akademik.

Konsep diri akademik yang tinggi akan membuat siswa menggunakan segala potensi dan kemampuannya seoptimal mungkin dengan jalan mengikuti proses pembelajaran dengan baik, individu tersebut akan menganggap dirinya sebagai orang yang berpotensi, cerdas maupun setara dengan orang yang pintar. Sebaliknya, konsep diri akademik yang rendah akan menunjukkan kurang percaya diri pada bakat atau kemampuan akademiknya, meremehkan atau menilai rendah bakatnya, menghindari situasi yang dapat menyebabkan kecemasan, kurang memiliki sumber daya kognitif, kurang memiliki motivasi yang positif, dan berkinerja rendah secara akademik.Hal ini dikarenakan konsep diri akademik mempunyaiperan penting dalam menentukan perilaku individu. Bagaimana individu memandang dirinya akan tampak dari seluruh perilakunya. Jika individu memandang dirinya sebagai orang yang tidak mempunyai cukup kemampuan untuk melakukan suatu tugas, maka seluruh perilakunya akan menunjukkan ketidakmampuannya tersebut(Surna dan Pandeirot, 2014:152).

Berdasarkan uraian di atas memperlihatkan bahwakonsepdiri akademikmemberikan kontribusi yang signifikan terhadap prestasi belajar Bahasa Inggris siswa. Dengan demikian, untuk meningkatkan prestasi belajar Bahasa Inggris siswa dapat diupayakan dengan meningkatkan konsep diri akademik.

\section{Kontribusi Motivasi terhadap Prestasi Belajar Bahasa Inggris}

Hasil penelitian menunjukkan bahwa motivasi berkontribusi secara signifikan terhadap prestasi belajar Bahasa Inggris. Temuan ini diperoleh berdasarkan analisis data yang menunjukkan bahwa kontribusi motivasi terhadap prestasi belajar Bahasa Inggris sebesar 32,9\%. Artinya, motivasi merupakan salah satu faktor yang berkontribusi atau menentukan prestasi belajar Bahasa Inggris siswa. Hal ini sesuai dengan 
yang dikemukakan oleh Dalyono (2010:235-236)bahwa motivasi menentukan baik tidaknya prestasi belajar siswa. Semakin besar motivasi siswa untuk belajar, semakin besar pula kesuksesan belajarnya. Siswayang motivasinya tinggi atau kuat akan giat berusaha, tampak gigih tidak mau menyerah, giat membaca buku-buku untuk meningkatkan prestasinya. Sebaliknya, siswa yang memiliki motivasi rendah atau lemah, tampak acuh tak acuh, mudah putus asa, perhatiannya tidak tertuju pada pelajaran, suka mengganggu kelas, sering meninggalkan pelajaran akibatnya banyak mengalami kesulitan belajar.

Purwanto (2007:61) juga mengemukakan bahwa nilai buruk yang diperoleh siswa pada mata pelajaran tertentu bukan karena anak itu bodoh terhadap mata pelajaran tersebut. Akan tetapi, karena siswa tersebut malas. Jika seseorang mendapat motivasi yang tepat, maka lepaslah tenaga yang luar biasa, sehingga tercapai hasil-hasil yang semula tidak terduga. Lebih lanjut, Marjohan (dalam Das dan Elfi, 2004:10) mengemukakan bahwa kebanyakan hasil belajar siswa kurang memuaskandi sekolah bukanlah disebabkan karena inteligensi dan bakat siswa yang bersangkutan rendah, melainkan disebabkan oleh semangat atau motivasi belajarnya rendah.Oleh karena itu, motivasi mengarahkan perilaku ke tujuan tertentu, meningkatkan usaha dan energi, meningkatkan prakarsa (inisiasi) dan kegigihan terhadap berbagai aktivitas, serta meningkatkan performa siswa untuk mencapai prestasi belajarnya(Ormrod, 2008:58-59).

Nachiappan (dalam Mardianto, 2013:193) juga mengemukakan bahwa, "Motivasi dianggap penggerak utama dalam menstruktur tingkah laku, pemikiran, emosi, hal tujuan, dan minat pelajar untuk mencapai prestasi belajarnya secara berkesan". Dalam artian, motivasi merupakan faktor penting dan yang mendasari siswa untuk belajar hingga mencapai prestasi belajarnya. Sehingga, Purwanto(2007:60) menegaskan bahwa motivasi merupakan syarat mutlak dalam belajar agar siswa dapat terhindar dari perilaku-perilaku belajar yang tidak baik. Tanpa motivasi, siswa tidak akan mungkin melakukan aktivitas belajar.

Berdasarkan uraian di atas memperlihatkan bahwamotivasi memberikan kontribusi yang signifikan terhadap prestasi belajar Bahasa Inggris siswa. Dengan demikian, untuk meningkatkan prestasi belajar Bahasa Inggris siswa dapat diupayakan dengan meningkatkan motivasi.

\section{Kontribusi Konsep Diri Akademik dan Motivasi terhadap Prestasi Belajar Bahasa Inggris}

Hasil penelitian menunjukkan bahwa konsep diri akademik dan motivasi secara bersama-sama berkontribusi secara signifikan terhadap prestasi belajar Bahasa Inggris. Temuan ini diperoleh berdasarkan analisis data yang menunjukkan bahwa kontribusi konsep diri akademik dan motivasi terhadap prestasi belajar Bahasa Inggris sebesar 60,1\%. Artinya, konsep diri akademik dan motivasi merupakan faktorfaktor yang dominan berkontribusi terhadap prestasi belajar Bahasa Inggris.Hal ini sesuai dengan yang dikemukakan oleh Liu (2009:414) bahwa konsep diriakademik merupakan salah satu penentu utama prestasi belajar. Caraterbaik untuk meningkatkan prestasi belajar siswa adalah meningkatkan konsep diri akademik. Lebih lanjut, Sardiman $(2014: 75,85)$ juga mengemukakan bahwa prestasi belajar atau hasil belajar akan optimal kalau ada motivasi yang tepat. Makin tepat motivasi yang diberikan, akan makin berhasil pula pelajaran itu. Bahkan, siswa yang memiliki inteligensi cukup tinggi sekalipun, boleh jadi gagal karena kekurangan motivasi. Hal ini dikarenakan motivasi berfungsi sebagai pendorong usaha dan pencapaian prestasi.

Berdasarkan paparan di atas, membuktikan bahwa konsep diri akademik dan motivasi secara bersamasama memberikan kontribusi yang signifikan terhadap prestasi belajar Bahasa Inggris. Dengan demikian, untuk meningkatkan prestasi belajar Bahasa Inggris siswa dapat diupayakan dengan meningkatkan konsep diri akademik dan motivasi.

\section{Implikasi dalam penyusunan program pelayanan BK di bidang belajar}

Berdasarkan hasil wawancara kepada guru BKdi SMAN 8 Padang pada tanggal 30-31 Oktober, dan 02 November 2015 dan hasil studi dokumentasi menunjukkan bahwa sebagian besar penyusunan program BK kelas XII SMAN 8 Padang T.A 2015/2016 telah tersusun dengan baik dan perihal materi yang berkaitan denganpeningkatan konsep diri akademik, motivasi, dan prestasi belajar siswa telah terkandung dan tertulis di dalam program BK yang telah disusun. Meskipun, perlu diadakannya evaluasi dan 
(Kontribusi Konsep Diri Akademik dan Motivasi Terhadap Prestasi Beljar Bahasa Inggris Serta Implikasinya dalam Penyususnan Program Pelayanan Bimbingan dan Konseling di Bidang

Belajar)

perbaikan yang lebih memadaı dan aktual terhadap program BK tersebut. Sehingga, pelayanan BK di sekolah dapat tepat sasaran, berdaya guna, berhasil guna, dan bermakna bagi siswa.

Berdasarkan uraian di atas terlihat bahwa sebagian besar penyusunan program BK kelas XII SMAN 8 Padang T.A 2015/2016 telah tersusun dengan baik dan perihal materi yang berkaitan denganpeningkatan konsep diri akademik, motivasi, dan prestasi belajar siswa telah terkandung dan tertulis di dalam program BK yang telah disusun.

\section{KESIMPULAN DAN SARAN}

\section{Kesimpulan}

Berdasarkan temuan dan pembahasan hasil penelitian, maka dapat dikemukakan kesimpulan sebagai berikut:

1. Secara rata-rata gambaran konsep diri akademik siswa berada pada kategori sedang.

2. Secara rata-rata gambaran motivasi siswa untuk belajar berada pada kategori tinggi.

3. Secara rata-rata gambaran prestasi belajar Bahasa Inggris siswa berada pada kategori baik. Akan tetapi, apabila berdasarkan KKM, ada beberapa siswa yang tidak tuntas.

4. Konsepdiri akademikmemberikan kontribusi terhadap prestasi belajar Bahasa Inggris siswa sebesar 20,3\%.

5. Motivasi memberikan kontribusiterhadap prestasi belajar Bahasa Inggris siswa sebesar 32,9\%.

6. Konsepdiri akademikdan motivasi memberikan kontribusi terhadap prestasi belajar Bahasa Inggris siswa secara bersama-sama sebesar $60,1 \%$.

7. Sebagian besar penyusunan program BK kelas XII SMAN 8 Padang T.A 2015/2016 telah tersusun dengan baik dan perihal materi yang berkaitan dengan peningkatan konsep diri akademik, motivasi, dan prestasi belajar siswa telah terkandung dan tertulis di dalam program BK yang telah disusun.

\section{Saran}

Berdasarkan hasil penelitian, pembahasan, dan kesimpulan yang telah dikemukakan di atas, maka terdapat beberapa saran yang dapat direkomendasikan sebagai berikut:

1. Bagi Siswa

Siswadiharapkan untuk meningkatkan lagi konsep diri akademiknya, terkhusus perasaan dan persepsi siswa tentang kompetensi akademiknya dan keterlibatannya dalam kegiatan belajar. Selanjutnya, siswa juga diharapkan mempertahankan dan meningkatkan lagi motivasi belajarnya meskipun secara rata-rata motivasinya telah baik.

2. Bagi Guru BK/Konselor

Diharapkan terus meningkatkan keterampilan dan profesionalitasnya dalam menyelenggarakan dan mengelola kegiatan profesional pelayanan BK di sekolah. Selain itu, guru BK/konselor juga diharapkan untuk meningkatkan profesionalitasnya dalam menyusun program BK agar pelayanan BK betul-betul berdaya guna, berhasil guna, dan bermakna bagi siswa.

3. Bagi Kepala sekolah

Diharapkan dapat memfasilitasi pelayanan BK di dalam pembelajaran maupun di luar pembelajaran. Selain itu, kepala sekolah juga disarankan untuk menerapkan Permendikbud No. 81 A Tahun 2013 tentang Implementasi Kurikulum pada lampiran IV-Bagian VII Konsep dan Strategi Layanan BK yang mengamanatkan kegiatan BK diselenggarakan di dalam kelas dan/atau di luar kelas dengan volume kegiatan 2 jam dan bukan 1 jam pembelajaran per kelas dalam satu minggu. Sehingga, kegiatan BK di sekolah maupun di luar sekolah dapat terselenggarakan dengan baik, efektif, berdaya guna, berhasil guna, dan bermakna bagi siswa.

4. Bagi Musyawarah Guru Bimbingan dan Konseling (MGBK).

Musyawarah Guru Bimbingan dan Konseling (MGBK) hendaknya mengadakan workshop atau seminarterkait upaya peningkatan konsep diri akademik, motivasi, dan prestasi belajar siswa demi membantu siswa dalam meraih prestasi belajar yang maksimal di sekolah. 
5. Bagi Kepala Dinas Pendidikan

Kepala Dinas Pendidikan hendaknya mengadakan pelatihan bagi guru BK/konselor dalam rangka meningkatkan keterampilan dan profesionalitasguru BK/konselordalam menyusun program BK, menyelenggarakan dan mengelola kegiatan pelayanan BK.

6. Bagi LPMP

Hasil penelitian ini dapat dijadikan bahan masukan penataran yang diadakannya, dalam rangka meningkatkan mutu pendidikan khususnya di bidang BK.

7. Bagi Peneliti lainnya

Perlu dilakukan penelitian lanjutan terutama yang berkaitan dengan variabel-variabel lain yangdiduga berkontribusi terhadap prestasi belajar Bahasa Inggris.

\section{DAFTAR RUJUKAN}

Burns, R. B. (1979). Konsep Diri: Teori, pengukuran, perkembangan, dan perilaku. Terjemahan oleh Eddy. 1993. Jakarta: Arcan.

Dalyono, M. (2010). Psikologi Pendidikan. Jakarta: Rineka Cipta.

Das, I., dan Elfi. (2004). Buku II Bimbingan Belajar: Belajar untuk belajar. Bukittinggi: Usaha Ikhlas.

Liu, H. J. (2009). "Exploring Changes in Academic Self-Concept in Ability-Grouped English Classes." Chang Gung Journal of Humanities and Social Sciences, 2: 411-432.

Mardianto. (2013). Psikologi Pendidikan: Landasan untuk pengembangan strategi pembelajaran. Medan: Perdana Publishing.

Ormrod, J. E. (2008). Psikologi Pendidikan: Membantu siswa tumbuh dan berkembang. Terjemahan oleh Amitya Kumara. 2009. Jakarta: Erlangga.

Prayitno, Wibowo, M. E., Marjohan, Mugiarso, H., dan Ifdil. (2014). Pembelajaran Melalui Pelayanan Bimbingan dan Konseling di Satuan Pendidikan. Padang: UNP Press.

Purwanto, M. N. (2007). Psikologi Pendidikan. Bandung: Remaja Rosdakarya Offset.

Sardiman, A. M. (2014). Interaksi dan Motivasi Belajar Mengajar. Jakarta: RajaGrafindo Persada.

Slameto. (2010). Belajar dan Faktor-faktor yang Mempengaruhinya. Jakarta: Rineka Cipta.

Surna, I. N., dan Pandeirot, O. D. (2014). Psikologi Pendidikan. Jakarta: Erlangga.

Tu’u, T. (2004). Peran Disiplin pada Perilaku dan Prestasi Siswa. Jakarta: Grasindo.

Villegas, G. O., Tomasini, G. A., dan Lagunes, L. I. R. (2013). "Development of an Academic Self Concept for Adolescents (ASCA) SCALE.” Journal of Behavior, Health, and Social Issues, 5: 117-130.

Yusuf, A. M. (2013). Metode Penelitian Kuantitatif, Kualitatif, dan Penelitian Gabungan. Padang: UNP Press. 